\title{
TSPAN32 wt Allele
}

National Cancer Institute

\section{Source}

National Cancer Institute. TSPAN32 wt Allele. NCI Thesaurus. Code C52373.

Human TSPAN32 wild-type allele is located in the vicinity of $11 \mathrm{p} 15.5$ and is approximately $16 \mathrm{~kb}$ in length. This allele, which encodes tetraspanin-32 protein, is involved in tumor suppression and may play a role in hematopoietic cell function. 